\title{
Collection of rape evidence in India - an analysis
}

\section{Introduction}

Rape is a crime committed by the hyper action of sex organs. In a case it was held that rape is a heinous crime and points towards beastly nature of entire society. It is also violative of victim's most cherished of the fundamental rights, namely the Right to Life Contained in Article 21 in Constitution of India. ${ }^{1}$ The basic cause for this offence is to ruin the respect of a female. The women are universally respected. In an offence of rape the investigation officer's at once seize those clothes of the victim girl (or women) which were/ are worn beneath the waist as those clothes would contain the stains of semen. This should be done without any delay as by washing of those clothes the stains may disappear and entire investigation may go waste. It is no secret that survivors of rape in India are humiliated and discriminated. They could face it in their own homes, police stations and then in the hospital where they undergo invasive medical tests that often end up doing little beyond harming their case later in the legal process. ${ }^{2}$ Females are raped and sexually assaulted more often than males. Male rape is committed by another man, often in prison. Males who are raped are more likely than females to be physically injured, to be unwilling to report the crime, and to have multiple assailants. ${ }^{3}$ In Indian Penal Code rape is defined in Section 375, according to which the rape is sexual illicit sexual relation with a female which is caused by penetration of penis of a male into vagina of female. As after the Criminal Amendment Act 2013 - Section 375 of Indian Penal Code, 1860 state that:

A man is said to commit "rape" if he

I. Penetrates his penis, to any extent, into the vagina, mouth urethra or anus of a woman or makes her to do so with him or any other person; or

II. inserts, to any extent, any object or a part of the body, not being the penis, into the vagina, the urethra or anus of a woman or makes her to do so with him or any other person; or

III. manipulates any part of the body of a woman so as to cause penetration into the vagina, urethra, anus or any part of body of such woman or makes her to do so with him or any other person; or

IV. applies his mouth to the vagina, anus, urethra of a woman or makes her to do so with him or any other person,

Under the circumstances falling under any of the following seven descriptions:

First - Against her will.

Secondly - Without her consent

Thirdly - With her consent when her consent has been obtained by putting her or any person in whom she is interested, in fear of death or of hurt.

${ }^{1}$ TK Gopal v. State of Karnataka (200) 6 SCC 168: State of Himachal Pradesh v. Shree Kant Shekhari (2004) 8 SCC 153: Bodhisattwa v. Subra AIR 1996 SC 922.

${ }^{2}$ Arun George, Doctors to Cops: the horror of rape examination in India, available at www.firstpost.com (accessed on 12th March 2013).

${ }^{3}$ Norah C. Feeny. Medical Examination of the Rape Victim, The Merck

Manual for health care professionals (July 2012).
Volume 6 Issue 6 - 2018

\author{
Himanshu Pandey,' Priyanka Dhar ${ }^{2}$ \\ 'Associate Professor of Law at Maharashtra National Law \\ University, Nagpur, India \\ ${ }^{2}$ Assistant Professor (Law) Galgotias University, Greater Noida, \\ India
}

Correspondence: Priyanka Dhar, Assistant Professor (Law) Galgotias University, Greater Noida, UP, Tel +919923156284, Email dharpreyanka6@gmail.com

Received: March 15, 2018| Published: December 03, 2018

Fourthly-With her consent, when the man knows that he is not her husband and that her consent is given because she believes that he is another man to whom she is or believes herself to be lawfully married.

Fifthly- With her consent when, at the time of giving such consent, by reason of unsoundness of mind or intoxication or the administration by him personally or through another of any stupefying or unwholesome substance, she is unable to understand the nature and consequences of that to which she gives consent.

Sixthly - With or without her consent, when she is under sixteen years of age

Seventhly -When she is unable to communicate consent.

Explanation 1 - For the purposes of this section, "vagina" shall also include labia majora.

Explanation 2 - Consent means an unequivocal voluntary agreement when the woman by words, gestures or any form of verbal or non-verbal communication, communicates willingness to participate in the specific sexual act:

Provided that a woman who does not physically resist to the act of penetration shall not by the reason only of that fact, be regarded as consenting to the sexual activity.

Exception 1.-A medical procedure or intervention shall not constitute rape.

Exception 2.- Sexual intercourse or sexual acts by a man with his own wife, the wife not being under fifteen years of age, is not rape.

\section{Judicial verdict}

The marks of struggle put by the victim female also suggest that sexual intercourse has been done on her without her consent because no rape can be committed unless the victim female is under the full control of rapist. Hence, to save her respect and modesty she tries to put every sort of struggle. It is seen that rape is not possible with a strong and health female except when the female is over powered by threat of death or when she become unconscious due to fear etc. ${ }^{4}$ The law on the point of consent for intercourse is very clear. Consent has no role if the age of the girl is below 15 years. The IPC recognizes the age of consent at Sixteen years. The consent should be with free

\footnotetext{
${ }^{4}$ Rao. Harnarain singh v. State of Punjab AIR 1958 Punjab 123.
} 
will. Consent under coercion or threat is no consent at all. ${ }^{5}$ As already stated complete penetration of penis of a man into a vagina of woman and its discharge is not necessary. The examination of sexual organs of both man and woman is necessary for proving rape. ${ }^{6}$

\section{Symptoms and signs}

Rape may result in the following:

I. Extra genital injury

II. Genital injury

III. Psychologic symptoms

IV. Sexually Transmitted Diseases (STDs - e.g. hepatitis, syphilis, gonorrhea, chlamydial infection, trichomoniasis, HIV infection [rarely])

V. Pregnancy (uncommonly)

Most physical injuries are relatively minor, but some lacerations of the upper vagina are severe. Additional injuries may result from being struck, pushed, stabbed, or shot. Psychologic symptoms of rape are potentially the most prominent. In the short term, most patients experience fear, nightmares, sleep problems, anger, embarrassment, shame, guilt, or a combination. Immediately after an assault, patient behaviour can range from talkativeness, tenseness, crying, and trembling to shock and disbelief with dispassion, quiescence, and smiling.

Goals of rape evaluation are -

I. Medical assessment and treatment of injuries and assessment, treatment, and prevention of pregnancy and STDs

II. Collection of forensic evidence

III. Psychological evaluation

IV. Psychological support

\section{Investigation and provision for examination of rapist}

U/s 228A of Indian Penal Code, No person can disclose the name of the rape victim and if anybody discloses the name, he shall be punished with either description for a term which may extend to two years and shall also be liable for fine. U/s 114-A of Indian Evidence Act, presumption can be made as to the absence of consent in certain prosecutions for rape. Whenever the person of a female victim is to be examined under section 53 of Criminal Procedure Code (Cr. P. $\mathrm{C})$, the examination shall be made only by, or under the supervision of, a female registered medical practitioner. ${ }^{7}$ Section 53A seeks to provide for a detailed medical examination of a person accused of an offence of rape or an attempt to commit rape by the registered medical practitioner employed in a hospital run by the Government or a local authority and in the absence of such a practitioner by any other registered medical practitioner. While investigating the case, the investigation officer should take the help of registered medical practitioner and he/she should proceed according to the provision for examination of rapist as given in Section 53-A, Cr.P.C. and the following point should be kept in mind:

i. Position of Criminal Act:

ii. Place, date and time of crime;

\footnotetext{
${ }^{5}$ Budhan Lal Sharma v. State (1961) Cri LJ 689.

${ }^{6}$ State of Karnataka v. Krishna Ji Narayan Murthi 1998 Cri LJ 2481.

${ }^{7} \mathrm{Sec} 53$ of Cr. P. C. Examination of accused by medical practitioner at the request of police officer- Nothing in this section shall be construed as rendering lawful any examination without the consent of the woman or of any person competent to give such consent on her behalf.
}

iii. Mental State of Victim, physical bodily injury;

iv. Statement of the victim to the crime, if any;

v. Place of occurrence and condition of its surroundings;

vi. Statement should be given before the female police officer;

vii. The marks of tear, semen or blood or saliva found on the clothes of the victim(s);

viii. Age of victim(s);

ix. Character of victim(s);

x. Statement of suspects;

xi. Sending the clothe, shoes, chappals, bad sheets, towel, carpet, pillow, fingerprints, footprints and blood, hair, saliva, semen stains, etc. to the laboratory for DNA fingerprinting or any scientific test;

xii. Any other relevant physical objects which may give some clue;

xiii. The victim(s) should be checked by some medical officers;

xiv. The victim(s) should be sent to hospital as soon as possible under the supervision of women constable for her examination.

$\mathrm{xv}$. The report shall state precisely the reasons for each conclusion arrived at.

xvi. The exact time of commencement and completion of the examination shall also be noted in the report.

The registered medical practitioner shall, without delay, forward the report to the investigating officer, who shall forward it to the Magistrate referred to in section 173 of Cr. P.C. as part of the documents referred to in clause (a) of sub-section (5) of that section.

Section 164 A of Cr. P. C. has been added by amendment in 2005, to provide for a medical examination (during the stage when an offence of committing rape or attempt to commit rape is under investigation) of the victim of a rape by a registered medical practitioner employed in a hospital run by the Government or a local authority and in the absence of such a practitioner by any other registered medical practitioner. U/s 327(2) of Code of Criminal Procedure, there should be in camera trial for all rape victims.

\section{The Impact of medico legal evidence in sexual assault cases}

The absence of uniform guidelines in gathering medical evidence for rape cases is one of the main reasons why conviction rate is so low. Only $26.4 \%$ of the 24,206 cases of rape that were registered in 2011 had convictions, according to National Crime Records Bureau. ${ }^{8}$

The principal features of the examination are:

i. Primary data

ii. Physical Examination and mental condition

iii. Sings of struggle on clothes and body

iv. Local examination of the genitals

Medical practitioners often focus on aspects that are not relevant to the investigation. Doctors document the sexual history of the victim, which may not always be relevant to the case. The Himachal Pradesh High Court ruled in 2008 that sexual history of the survivor was not at all relevant to the rape case. Doctors use the archaic two-finger test to determine how habituated the survivor is to sexual intercourse. This information may disrespect the character of the victim. A Sessions Court in New Delhi ruled in 2010 that the two-finger test violated the privacy of the victim and needed to be stopped. There is also a lack of co-ordination between the hospital where the medical examination ${ }^{8}$ Sunil Sharma53/examination-of-rapeaccused- 2 (Accessed on 23rd March
2013). 
is carried out and the forensic laboratory where the evidence is sent As a result, hospitals often do not get a copy of the chemical analysis report, although the doctor who conducted the medical examination is supposed to give his /her opinion based on the report.

\section{Order of collection of Evidence}

\section{Clothing}

Trace evidence from the patient's clothes will not be lost if the patient is instructed to undress over a large sheet of paper (drop sheet). One way of doing this is to ask the patient to stand on a sheet of paper, behind a screen and hand out the items of clothing one by one, to be placed in individual paper bags. Check with the police which items of clothing are required.

\section{Drop sheet}

The drop sheet could have evidence from the offender such as pubic hairs, head hairs and clothing fibres.

The drop sheet could have evidence from the scene such as sand, fibres or vegetation.

The drop sheet is folded in such a way so as to retain any evidence, placed in a paper bag and sealed with a patient label.

\section{Sanitary pad/tampon}

These items should be dried and sealed in a double paper bag.

\section{Fingernail scrapings}

An allegation of the victim scratching the assailant may leave foreign DNA or fibres under the patient's fingernails. A wooden swab stick may be broken in half, one used for each hand, and the remnants placed in a sterile urine jar. Alternatively, the fingernail(s) can be cut and the clippings placed in the container.

\section{Head hair for comparison purposes}

Twenty representative hairs should be cut from over the head, placed on a piece of paper, folded as the drop sheet, sealed and bagged.

\section{Oral swab}

Spermatozoa in the mouth collect in the same places as saliva. The best reservoirs are therefore the gingival margins of the lower teeth and under the tongue. This swab should be done if there is allegation of oral penetration within the last 12-24 hours. Alternatively, have the patient his/her mouth with $20-30 \mathrm{ml}$ of sterile water and collect the rinsings in a sterile container.

\section{Saliva on skin}

Assailant DNA can be recovered. The double swab technique involves (a) swabbing the affected area with a swab moistened with tap water, followed by (b) swabbing with a dry swab. Both swabs should be air dried and submitted.

\section{Semen on skin}

The double swab technique can be also be used for skin where dried semen may be present. Both the first moist swab and the second dry swab should have slides made from them. Use this technique wherever ejaculation may have occurred, including the vulva and anus.

\section{Pubic hair combing}

Performed infrequently and only if foreign hair is noted on examination. Submit comb and products. Collect foreign materials with a swab stick and submit in a sterile container.

\section{Vaginal swab}

A swab taken with or without the use of a speculum, depending on patient/doctor preference.

\section{Endocervical swab}

Can be collected with the use of a speculum for direct visualization of the cervix. Use warm water to lubricate the speculum.

\section{Anal and rectal swab}

An anoscope may be used, or the anus can be swabbed under direct vision.

\section{Victim / Assailant DNA for comparison}

If there is no allegation of oral penetration, a buccal swab may be taken. Otherwise, blood will provide DNA.

\section{Blood for DNA}

Should be collected into an appropriate tube.

\section{Blood for drugs}

Use a plain tube.

\section{Urine for drugs}

Instruct the patient to provide a full sterile container of urine.

\section{Part of the body affected by the sexual offences}

\section{Parts of female Bodies}

i. Vulva;

ii. Labia Majora;

iii. Labia Minora;

iv. Mons Veneris;

v. Clitoris;

vi. Urethra;

vii. Hymen;

viii. Vaginal Orifice;

ix. Vagina;

x. Menstrual fluid;

xi. Pubic hair;

xii. Female anus.

\section{Parts of male bodies}

i. penis

ii. Root

iii. Body

iv. Glans penis

v. Cervix Uteri

vi. Prepuce

vii. Pubic hair

viii. Male Anus.

\section{Rape and views of courts}

\section{The tearing of hymen}

By medical evidence, it was apparent that there was swelling in vagina and hymen was torn. There was pain in private parts. Vagina 
admitted one finger. Blood stain was on the cloth of girl. Held that it was possible that vaginal hole was constricted after sexual intercourse. Tearing of hymen was enough to constitute the offence of rape. ${ }^{9}$ In view of the doctor the hymen was torn long ago. There was blood discharge from vagina and semen was absent. The salwar of victim was full of blood. Non- finding of sperm on the vagina does not rule out the rape. ${ }^{10}$ It was the allegation that a healthy person has raped a girl aged between 7-10 years. No damage was found in the penis although the hymen was torn. There was no blood discharge on it. The doctor did not find the signs of scratch, swelling, redness etc. The court held that rape was not proved. It was alleged that the girl was minor and was kidnapped and was raped. Victim was medically examined but definite opinion of rape was not given in report. However, hymen was absent. Old healed tears were found. The radiologist was asked for fixation of age but the prosecution could not produce any such report. Appeal was partly allowed. ${ }^{11}$ In one case the doctor found discharge of blood from the private parts of the victim girl. The dress worn by the victim girl at the time of occurrence was also wet by blood. Her entire private parts from anus to vagina were torn and blood was coming out from the torn parts. Her vaginal membrane was also torn. Appellant was unknown to her. The victim's stand was supported by the evidences of P.Ws. It was held by the court that rape was done. ${ }^{12}$ According to the medical examination rape was committed on the victim. It was due to the fact that vaginal membrane was torn and blood was coming out. There were scratch marks on her right breast. She complained of pain in both the legs and neck. The Supreme Court while upholding the view of the High Court held that it was the case of first sexual intercourse with her. According to the High Court the swelling on the inner walls of the vagina had occurred due to mass violent rape of her by many persons. During cross-examination the father of the victim girl gave evidence (statement) that she was found in an unconscious state and she remained unconscious till sunset. His statement had corroborated the statement of the victim girl. Hence supporting the judgments of the trial Court the Supreme Court also found the appellant guilty of rape. ${ }^{13}$ After the examination of the victim the doctor had shown in his medical report that the secondary sex signs were not developed. There was absence of auxiliary and pubic hairs. There was a scratch mark of $3 / 8$ " X $2 / 8$ " on the waist. The membrane of the upper part of the vagina was absent and the ends of the vagina were torn and were tender. There was blood discharge on the upper part of the vagina and it hardly admitted one finger. There were blood stains on the salwar of the victim which was sealed. Unfortunately the lady doctor could not be presented for evidence but on leave of court another doctor, who had worked with the lady doctor for two years had proved her signature. The counsel for the accused gave his logic that it was not advisable to believe the carbon copy in absence of original copy of the report. Section 32 of the evidence provides when a person of such profession is not in-charge of affairs than a report, oral or in writing, by him is admissible in evidence. Doctor had also examined the accused and opined that hair was present on his private parts and the penis and testicles were full developed. It was also said that vagina admitted one finger with difficulty. Hence, it was not acceptable that penis was penetrated in vagina. It was surprising that doctor has not opined his clear view on it. Doctor found the age of victim between

\footnotetext{
${ }^{9}$ Prithi Chand v. State of H.P. AIR 1989 SC 702.

${ }^{10}$ Ibid.

${ }^{11}$ Iqbal Hussain v. M.P. State 1989 Cri L J 17 (MP)

${ }^{12}$ Om Prakash v. State 1987 (1) Crimes 645 (Del).

${ }^{13}$ Balwant Singh v. State of Punjab \& Saudagar Singh v. State of Punjab 1987(1) Cri L J 910 (SC).
}

$8-1 / 2$ to 12 years. No sperm was found on the cloths. Prosecution had explained the delay in lodging the FIR. The Supreme Court upheld the decision of the Trial Court and the High Court. ${ }^{14}$

\section{Finding of blood and semen on vagina}

It was alleged that the accused had lowered down the petticoat of the complainant in night and had sat on her back. It was also said that she was awaken at that time. According to medical evidence neither there was blood nor semen stain on her vagina or cloths. No penetration was done. Rape was not proved. ${ }^{15}$ By medical evidence, it was proved that there was sperm in the vagina. Rape was also opined in Medical Report. Rape was proved. ${ }^{16}$

The victim said that accused had wiped out her vaginal discharge with the help of towel. Towel could not be recovered during investigation. This did not prove the statement of complainant/ victim. ${ }^{17}$ In medical examination no stain of semen was found. There was no blood stain on the underwear of the complainant and the hymen was also not torn. It was held that no penis penetration was done. ${ }^{18}$ For six days the complainant discloses the name of the accused. No sign of rape was fund by the Doctor on the vagina of the girl. Genital organs - cervix, labia or vulva were intact. No sperm was found. It was held that rape was not proved. ${ }^{19}$

\section{Finding of semen stains in the cloths}

The finding of sperm on the quilt was relevant where complainant had said that rape was committed on the quilt..$^{20}$ The petticoat of the complainant which was stained with semen was neither kept in sealed cover nor was sent for chemical examination. Medical evidence didn't support the offence of rape. It was the case of acquittal. ${ }^{21}$ Mere finding of semen stain in the cloths of accused and victim woman do not establish intercourse unless supported by other evidences. ${ }^{22}$ In an instant case it was alleged that penis was fully penetrated but no stain of semen was found on the vagina of the complainant. No signs of rape were present on the accused. Non detection of sperm on vagina was tried to be supported by saying that sperm can be found up to 24 hours or from 3 to 5 days in uterine cavity. It was said that the principle was true in respect of living female but there were doubts about applicability of this principle in respect of a dead woman. The question was not referred to the medical examination after 24 hours of intercourse is meaningless. ${ }^{23}$

\section{Legal definition of DNA}

Among the many new tools that science has provided for the analysis of forensic evidence is the powerful and controversial analysis of deoxyribonucleic acid, or DNA, the material that makes up the genetic code of most organisms. DNA analysis, also called DNA typing or DNA profiling, examines DNA found in physical evidence such as blood, hair, and semen, and determines whether it can be matched to DNA taken from specific individuals. DNA analysis has become a common form of evidence in criminal trials. It is also used

\footnotetext{
${ }^{14}$ Prithi Chand v. State of HP AIR 1989 SC 702.

${ }^{15}$ Ankaraiya v. State of MP 1991 Cri LJ 751 (MP).

${ }^{16}$ Jairaj v. State of Karnataka 1991 (1) Crimes 278 (Karn).

${ }^{17}$ Yado Ram v. State 1972 Cri LJ 1464 (J\&K).

${ }^{18}$ Ravindra v. State of Maharashtra 1989 Cri LJ 394.

${ }^{19}$ Raya Bhim v. State of Gujarat 1987 (3) Crimes 573 (Raj)

${ }^{20}$ Harendra v. Emperor AIR 1940 Cal 461.

${ }^{21}$ Naku Singh v. State of UP 1984 ALJ 548

${ }^{22}$ State of Orissa v. Musa 1991 Cri LJ 2168 (Ori).

${ }^{23}$ S.P. Kohli v. Punjab \& Haryana Court AIR 1978 SC 1753.
} 
in civil litigation, particularly in cases involving the determination of Paternity of Identity. ${ }^{24}$

\section{Interpreting results of DNA analysis in criminal investigation \\ Inclusion}

When the DNA profile of a known individual (A victim or suspect) matches the DNA profile from the crime scene evidence, the individual is "included" as a potential source of that evidence.

\section{Exclusion}

When the DNA profile from an individual (A victim or suspect) does not match the DNA profile generated from the crime scene evidence, the referenced individual is "excluded" as the donor of the evidence.

\section{Inconclusive}

Inconclusive results indicate that DNA testing did not produce information that would allow an individual to be either included or excluded as the source of the biological evidence.

\section{Queries regarding DNA analysis among common people}

If I am arrested by the police for a crime, do the police have the right to order me to provide a DNA sample for their criminal investigation? If a family member commits a crime, can his DNA at the crime scene lead law enforcement to wrongly believe that I committed the crime? How similar is DNA among family members?

What procedures can I take if I believe that DNA evidence found at a crime scene was accidently contaminated by police during the collection process?

\section{DNA profiling and Indian legal system}

The admissibility of the DNA evidence before the court always depends on its accurate and proper collection, preservation and documentation which can satisfy the court that the evidence which has been put in front it is reliable. There is no specific legislation which is present in Indian which can provide specific guidelines to the investigating agencies and the court, and the procedure to be adopted in the cases involving DNA as its evidence. Moreover, there is no specific provision under Indian Evidenced Act, 1872 and Code of Criminal Procedure, 1973 to manage science, technology and forensic science issues. Due to lack of having any such provision, an investigating officer has to face much trouble in collecting evidences which involves modern mechanism to prove the accused person guilty. Section 53 of Code of Criminal Procedure1973 authorizes a police officer to get the assistance of a medical practitioner in good faith for the propose of the investigation. But, it doesn't enable a complainant to collect blood, semen etc for bringing the criminal charges against the accused. The amendment of Cr. P. C. by the Cr. P. C. (amendment) Act, 2005 has brought two new sections which authorize the investigating officer to collect DNA sample from the body of the accused and the victim with the help of medical practitioner. These sections allow examination of person accused of rape by medical practitioner and the medical examination of the rape victim respectively. But the admissibility of these evidences has remained in a state of doubt as

${ }^{24}$ International Journal of Humanities and Social Science Invention ISSN (Online): 2319 - 7722, ISSN (Print): 2319 -7714 www.ijhssi.org Volume 2 Issue 7|| July 2013\| PP.15-21. the opinion of the Supreme Court and various High Courts in various decisions remained conflicting. Judges do not deny the scientific accuracy and conclusiveness of DNA testing, but in some cases they do not admit these evidences on the ground of legal or constitutional prohibition and sometimes the public policy. There is an argent need to re-examine these sections and lows as there is no rule present in the Indian Evidence Act, 1872 and Code of Criminal Procedure, 1973 to manage science and technology issues. Many developed countries have been forced to change their legislation after the introduction of the DNA testing in the legal system. There are certain provisions which are present in the Indian Evidence Act, 1872 such as section 112 which determine child's parentage and states that a child born in a valid marriage between a mother and a man within 280 days of the dissolution of the marriage, and the mother remaining unmarried shows that the child belongs to the man, unless proved otherwise but again no specific provision which would cover modern scientific techniques. DNA analysis is of utmost importance in determining the paternity of a child in the cases of civil disputes. Need of this evidence is most significant in the criminal cases, civil cases, and in the maintenance proceeding in the criminal courts under Section 125 of the Cr. P. C. The introduction of the DNA technology has posed serious challenge to some legal and functional rights of an individual such as "Right to privacy", "Right against Self-incrimination". And this is the most important reason why courts sometimes are reluctant in accepting the evidence based on DNA technology. Right to Privacy has been included under Right to Life and Personal liberty or Article 21 of the Indian Constitution, and Article 20(3) provides Right against Self- Incrimination which protects an accused person in criminal cases from providing evidences against him or evidence which can make him guilty. But it has been held by the Supreme Court on several occasions that Right to Life and Personal Liberty is not an absolute Right. In Govind Singh v. state of Madhya Pradesh ${ }^{25}$ Supreme Court held that a fundamental right must be subject to restriction on the basis of compelling public interest. In another case Khark Singh $v$. State of utter Pradesh, ${ }^{26}$ Supreme Court held that Right to privacy is not a guaranteed right under our Constitution. It is clear from various decisions which have been delivered by the Supreme Court from time to time that the Right to Life and Personal Liberty which has been guaranteed under our Indian Constitutions not an absolute one and it can be subject to some restriction. And it is on this basis that the constitutionality of the lows affecting Right to Life and Personal Liberty are upheld by the Supreme Court which includes medical examination. And it is on the basis that various courts in the country have allowed DNA technology to be used in the investigation and in producing evidence. To make sure that modern technologies can be used effectively, there is an urgent need of a specific legislation which would provide the guidelines regulating DNA testing in India. The recent refusal of the Supreme Court to dismiss the Delhi High court's decision ordering veteran congress leader N.D. Tiwari to undergo the DNA test is very important from the viewpoint of the admissibility of such evidence. In this case, Rohit Shekhar has claimed to be the biological son of N.D. Tiwari, but N.D. Tiwari is reluctant to undergo such test stating that it would be the violation of his Right to privacy and would cause him public humiliation. But Supreme Court rejected this point stating when the result of the test would not be revealed to anyone and it would under a sealed envelope, there is no point of getting humiliated. Supreme Court further stated that we want young man to get justice; he should not left without any remedy. It would

\footnotetext{
${ }^{25}$ Govind Singh v. State of MP AIR 1975 SC 1378

${ }^{26}$ Kharak Singh v. State of UP AIR 1963 SC 1295.
} 
be very interesting to see that how courts in India would allow the admissibility of DNA technology in the future. ${ }^{27}$

\section{International perspective on admissibility of DNA in criminal justice system}

i. In the 1950s, Anna Anderson claimed that she was Grand Duchess Anastasia Nikolaevna of Russia. In the 1980s, after her death, samples of her tissue that had been stored at a Charlottesville, Virginia hospital following a medical procedure were tested using DNA fingerprinting, and showed that she bore no relation to the Romanovs.

ii. In 1986, Richard Buckland was exonerated, despite having admitted to the rape and murder of a teenager near Leicester, the city where DNA profiling was first discovered. This was the first use of DNA finger printing in a criminal investigation.

iii. In 1987, genetic fingerprinting was used in criminal court for the first time in the trial of a man accused of unlawful intercourse with a mentally handicapped 14-year-old female who gave birth to his baby.

iv. In 1987, Florida rapist Tommy Lee Andrews was the first person in the United States to be convicted as a result of DNA evidence, for raping a woman during a burglary; he was convicted on November 6, 1987, and sentenced to 22 years in prison.

v. In 1989, Chicago man Gary Dotson was the first person whose conviction was overturned using DNA evidence.

vi. In 1991, Allan Legere was the first Canadian to be convicted as a result of DNA evidence, for four murders he had committed while an escaped prisoner in 1989. During his trial, his defence argued that the relatively shallow gene pool of the region could lead to false positives.

vii. In 1992, DNA evidence was used to prove that Nazi doctor Josef Mengele was buried in Brazil under the name Wolfgang Gerhard.

viii. In 1992, DNA from a palo verde tree was used to convict Mark Alan Bogan of murder. DNA from seed pods of a tree at the crime scene was found to match that of seed pods found in Bogan's truck. This is the first instance of plant DNA admitted in a criminal case.

ix. In 1993, Kirk Bloods worth was the first person to have been convicted of murder and sentenced to death, whose conviction was overturned using DNA evidence.

x. The 1993 rape and murder of Mia Zapata, lead singer for the Seattle punk band The Gits was unsolved nine years after the murder. A database search in 2001 failed, but the killer's DNA was collected when he was arrested in Florida for burglary and domestic abuse in 2002.

xi. In 2001, Wayne Butler was convicted for the murder of Celia Douty. It was the first murder in Australia to be solved using DNA profiling.

xii. In March 2003, Josiah Sutton was released from prison after serving four years of a twelve-year sentence for a sexual assault charge. Questionable DNA samples taken from Sutton were retested in the wake of the Houston Police Department's crime lab scandal of mishandling DNA evidence.

xiii. In June 2003, because of new DNA evidence, Dennis Halstead, John Kogut and John Restivo won a re-trial on their murder conviction. The three men had already served eighteen years of their thirty-plus-year sentences.

xiv. The trial of Robert Pickton (convicted in December 2003) is

${ }^{27}$ Rohit Shekhar v. Shri Narayan Dutt Tiwari IA No. 10394/2011 in CS(OS) No. $700 / 2008$. notable in that DNA evidence is being used primarily to identify the victims, and in many cases to prove their existence.

xv. In March 2009, Sean Hodgson who spent 27 years in jail, convicted of killing Teresa De Simone, 22, in her car in Southampton 30 years ago was released by senior judges. Tests prove DNA from the scene was not his. British police have now reopened the case.

\section{Indian perspective on admissibility of DNA in Indian legal system}

The use of DNA as evidence in criminal investigations has grown in recent years in India. DNA testing has helped law enforcement, identify criminals and solve difficult crimes. On the other hand, DNA evidence has supported proves that many convicted people are actually innocent. ${ }^{28}$

\section{DNA test in swami premanand's case}

The renowned swami Premanand had a number of female and male disciples. One of his female disciples told her brother that swamiji had raped her and she became pregnant. She managed to escape from the Ashram and lodged FIR question of paternity of child arose, hence the court directed the DNA test for determining the paternity of the children. The blood samples of baby, swamiji and of disciple were taken and analyzed which confirmed that swamiji was the father of the child. On the basis of this DNA test the swamiji was convicted. ${ }^{29}$

\section{DNA test in Handwara (Srinagar) rape case}

An Army Major charged with raping a woman and her daughter. The major throughout denied the charges. The blood samples of the alleged of the victims and the accused were sent to Central Forensic Laboratory, Chandigarh. The result of DNA test showed that the Army major was not involved in the alleged crime. Thus, the DNA test came to the rescue of major. ${ }^{30}$

\section{DNAT test in rape case in prison}

A woman and husband were lodged in different wards in jail on the charge of murder. The female charged jail official for raping her. During a regular medical check up, she was found pregnant. There was no possibility of cohabitation by husband as they were lodged separately. The court has order DNA test for 12 people including five policemen and four prisoners. ${ }^{31}$ This shows that DNA test help in proving person innocent or accused.

\section{The court order DNA test of foetus of rape victim}

A Division Bench of Delhi High Court ordered that DNA test to be conducted on a foetus of a rape victim. ${ }^{32}$

\section{The court ordered medical termination of pregnancy and DNA test of foetus in a rape case}

The narration of events as given by the victim in the petition and the counter filed by the respondents would clearly show that the victim (she) was raped by several persons on several dates against her will.

\footnotetext{
${ }^{28}$ Thograni v. State of Orissa 2004 Cri LJ 4003 (4007) (ori).

29 Lyon's Medical Jurisprudence and Toxicology, 11th Edition, p 167; kamalanantha v. State of Tamil Nadu Appeal (crl.) 611-12 of 2003.

${ }^{30}$ Econnect India Limited, 2000.

${ }^{31}$ Step Prisoner Rape Home. [result of Such DNA test were not available at that time on the internet site when this matter is taken from it.

${ }^{32}$ Geeta Saha v. NCT of Delhi 1999 (1) JCC 101 (DB).
} 
Besides the allegation of rape, as contained in the records filed by both the parties, the mental anguish and agony and grave injury to her mental being suffered by the petitioner due to continuance of the unwanted pregnancy in her womb is also clear spelt by the petitioner herself in her affidavit. Having regard to the factual position as narrated by the petitioner, which was not disputed by the petitioner, which was not disputed by the respondents. The court was constrained to come to the conclusion that unless the pregnancy of the petitioner is terminated, not only the mental shock and anguish would be caused, but also an irreparable loss would be caused to her, which cannot be remedied. The court directed the Chairman and Superintended, Government Kasturba Gandhi Hospital for women and children, Madras-5, to conduct medical termination of pregnancy of the petitioner and preserve foetus to enable the investigating agency to ask for DNA test, which would be helpful in order to prove the case of rape, alleged by the petitioner, against the persons during the course of trial also directed the investigation agency to continue the investigation and to file report under Section 173, Cr.P.C. ${ }^{33}$ In January, 1996 a law student of Delhi University was raped and strangulated in a South Delhi Flat. The trial Court did not believe the findings of Forensic Laboratory as the cloths which were sent to DNA testing were in a broken seal packet and thus there was possibility that biological evidence might have been tempered with. ${ }^{34}$

\section{Vaginal swab as a source of biological evidence}

DNA test in rape case of a medical student of maulana azad medical college, New Delhi

On $15^{\text {th }}$ November 2002 , three persons raped a fourth year girl student of Maulana Azad Medical College on the terrace of khooni darwaza, as historical monument. The police arrested suspected persons. Blood samples of one of the suspects were taken for DNA test. The samples were sent to DNA Fingerprinting and Diagnostic Laboratory, Hyderabad. The result of the test showed that blood samples matched with the vaginal semen and DNA sample found on sanitary pad of the victim. Thus the main accused could be identified by the help of DNA. ${ }^{35}$ The police took samples of swab from the victim, her underwear and mouth swab sample of the accused. There was absence of semen from the clothes. Non - finding of semen does not mean that there was no rape. If DNA matched than it could be said that sexual assault was done. ${ }^{36}$

\section{DNA evidence is admissible in court of law}

In an instant case DNA evidence given by expert witness CCMB, Hyderabad was accepted by the court. The court said that expert witness had himself participated in the conduct of the experiment and he had demonstrated his evidence with proof to the court with authentic and reliable technique. ${ }^{37}$

\section{Changes in collection of rape evidence after criminal amendment Act, 2013}

Amendments to the code of criminal procedure, 1973

\section{Section 11 of the act}

\footnotetext{
${ }^{33}$ Rajeshwari v. State of Tamil Nadu 1996 Cri LJ 3795 (3799) (Mad).

${ }^{34}$ United News of India; Deepak Ratan \& Mohd. H. Zaidi, Forensic Science in

India and the World, Alia Law Agency, Allahabad, 2008, p. 225.

${ }^{35}$ www.rediff.com/news/ 2003/apr/23 mamc.htm.

${ }^{36}$ News \& slair, 26th feb, 2005.

${ }^{37}$ Chandradevi v. State of Tamil Nadu Manu/TN/2335/2002.
}

In the Code of Criminal Procedure, 1973 (hereafter in this Chapter referred to as the Code of Criminal Procedure), in section 26, in the proviso to clause $(a)$, for the words, figures and letters "offence under section 376 and sections 376 A to 376 D of the Indian Penal Code", the words, figures and letters "offence under section 376, section 376A, section $376 \mathrm{~B}$, section $376 \mathrm{C}$, section $376 \mathrm{D}$ or section $376 \mathrm{E}$ of the Indian Penal Code" shall be substituted.

\section{Section 12 of the Act}

In section 54A of the Code of Criminal Procedure, the following provisos shall be inserted, namely: "Provided that, if the person identifying the person arrested is mentally or physically disabled, such process of identification shall take place under the supervision of a Judicial Magistrate who shall take appropriate steps to ensure that such person identifies the person arrested using methods that person is comfortable with: Gang rape provided further that if the person identifying the person arrested is mentally or physically disabled, the identification process shall be videographed."

\section{Section 13}

In section 154 of the Code of Criminal Procedure, in sub-section (1), the following provisos shall be inserted, namely:- "Provided that if the information is given by the woman against whom an offence under section 326A, section 326B, section 354, section 354A, section $354 \mathrm{~B}$, section $354 \mathrm{C}$, section $354 \mathrm{D}$, section 376 , section $376 \mathrm{~A}$, section 376B, section 376C, section 376D, section 376E or section 509 of the Indian Penal Code is alleged to have been committed or attempted, then such information shall be recorded, by a woman police officer or any woman officer provided further that

i. in the event that the person against whom an offence under section 354, section 354A, section 354B, section 354C, section 354D, section 376 , section $376 \mathrm{~A}$, section $376 \mathrm{~B}$, section $376 \mathrm{C}$, section $376 \mathrm{D}$, section $376 \mathrm{E}$ or section 509 of the Indian Penal Code is alleged to have been committed or attempted, is temporarily or permanently mentally or physically disabled, then such information shall be recorded by a police officer, at the residence of the person seeking to report such offence or at a convenient place of such person's choice, in the presence of an interpreter or a special educator, as the case may be;

ii. The recording of such information shall be videographed;

iii. The police officer shall get the statement of the person recorded by a Judicial Magistrate under clause $(a)$ of sub-section $(5 A)$ of section 164 as soon as possible."

\section{Section 14}

In section 160 of the Code of Criminal Procedure, in sub-section (1), in the proviso, for the words "under the age of fifteen years or woman", the words "under the age of fifteen years or above the age of sixty-five years or a woman or a mentally or physically disabled person" shall be substituted.

\section{Section 15}

In section 161 of the Code of Criminal Procedure, in sub-section (3), after the proviso, the following proviso shall be inserted, namely:- "Provided further that the statement of a woman against whom an offence under section 354, section 354A, section 354B, section $354 \mathrm{C}$, section $354 \mathrm{D}$, section 376 , section $376 \mathrm{~A}$, section $376 \mathrm{~B}$, section $376 \mathrm{C}$, section $376 \mathrm{D}$, section $376 \mathrm{E}$ or section 509 of the Indian Penal Code is alleged to have been committed or attempted shall be recorded, by a woman police officer or any woman officer." 


\section{Section 16}

In section 164 of the Code of Criminal Procedure, after subsection (5), the following sub-section shall be inserted, namely:" $(5 A)(a)$ In cases punishable under section 354 , section $354 \mathrm{~A}$, section 354B, section 354C, section 354D, sub-section (1) or sub-section (2) of section 376, section 376A, section 376B, section 376C, section $376 \mathrm{D}$, section $376 \mathrm{E}$ or section 509 of the Indian Penal Code, the Judicial Magistrate shall record the statement of the person against whom such offence has been committed in the manner prescribed in sub-section (5), as soon as the commission of the offence is brought to the notice of the police: Provided that if the person making the statement is temporarily or permanently mentally or physically disabled, the Magistrate shall take the assistance of an interpreter or a special educator in recording the statement: Provided further that if the person making the statement is temporarily or permanently mentally or physically disabled, the statement made by the person, with the assistance of an interpreter or a special educator, shall be videographed. (b) A statement recorded under clause $(a)$ of a person, who is temporarily or permanently mentally or physically disabled, shall be considered a statement in lieu of examination-in-chief, as specified in section 137 of the Indian Evidence Act, 1872 such that the maker of the statement can be cross-examined on such statement, without the need for recording the same at the time of trial."

\section{Section 17}

In section 173 of the Code of Criminal Procedure, in sub-section (2), in sub-clause $(h)$ of clause $(i)$, for the words, figures and letter "or section 376D of the Indian Penal Code", the words, figures and letters "section 376D or section 376E of the Indian Penal Code" shall be substituted.

\section{Section 18}

In section 197 of the Code of Criminal Procedure, after subsection (1), the following Explanation shall be inserted, namely: "Explanation.-For the removal of doubts it is hereby declared that no sanction shall be required in case of a public servant accused of any offence alleged to have been committed under section 166A, section $166 \mathrm{~B}$, section 354 , section $354 \mathrm{~A}$, section $354 \mathrm{~B}$, section $354 \mathrm{C}$, section $354 \mathrm{D}$, section 370 , section 375 , section 376 , section $376 \mathrm{~A}$, section 376C, section 376D or section 509 of the Indian Penal Code."

\section{Section 19}

After section 198A of the Code of Criminal Procedure, the following section shall be inserted, namely: — "198B. No Court shall take cognizance of an offence punishable under section 376B of the Indian Penal Code where the persons are in a marital relationship, except upon prima facie satisfaction of the facts which constitute the offence upon a complaint having been filed or made by the wife against the husband."

\section{Section 20}

In section 273 of the Code of Criminal Procedure, before the Explanation, the following proviso shall be inserted, namely: "Provided that where the evidence of a woman below the age of eighteen years who is alleged to have been subjected to rape or any other sexual offence, is to be recorded, the court may take appropriate measures to ensure that such woman is not confronted by the accused while at the same time ensuring the right of cross-examination of the accused."

\section{Section 21}

In section 309 of the Code of Criminal Procedure, for sub-section (1), the following sub-section shall be substituted, namely: "(1) In every inquiry or trial the proceedings shall be continued from day-today until all the witnesses in attendance have been examined, unless the Court finds the adjournment of the same beyond the following day to be necessary for reasons to be recorded: Provided that when the inquiry or trial relates to an offence under section 376 , section $376 \mathrm{~A}$, section $376 \mathrm{~B}$, section $376 \mathrm{C}$ or section $376 \mathrm{D}$ of the Indian Penal Code, the inquiry or trial shall, as far as possible be completed within a period of two months from the date of filing of the charge sheet."

\section{Section 22}

In section 327 of the Code of Criminal Procedure, in sub-section (2), for the words, figures and letter "or section 376D of the Indian Penal Code", the words, figures and letters "section 376D or section $376 \mathrm{E}$ of the Indian Penal Code" shall be substituted.

\section{Section 23}

After section 357A of the Code of Criminal Procedure, the following section shall be inserted, namely:

"357B. The compensation payable by the State Government under section 357A shall be in addition to the payment of fine to the victim under section 326A or section 376D of the Indian Penal Code. "357C. All hospitals, public or private, whether run by the Central Government, the State Government, local bodies or any other person, shall immediately, provide the first-aid or medical treatment, free of cost, to the victims of any offence covered under section 326A, 376, $376 \mathrm{~A}, 376 \mathrm{~B}, 376 \mathrm{C}, 376 \mathrm{D}$ or section $376 \mathrm{E}$ of the Indian Penal Code, and shall immediately inform the police of such incident."

\section{Amendments to the Indian evidence act, 1872}

\section{Section - 25}

After section 53 of the Indian Evidence Act, 1872 (hereafter in this Chapter referred to as the Evidence Act), the following section shall be inserted, namely: " $53 \mathrm{~A}$. In a prosecution for an offence under section 354, section 354A, section 354B, section 354C, section 354D, section 376 , section $376 \mathrm{~A}$, section $376 \mathrm{~B}$, section $376 \mathrm{C}$, section $376 \mathrm{D}$ or section $376 \mathrm{E}$ of the Indian Penal Code or for attempt to commit any such offence, where the question of consent is in issue, evidence of the character of the victim or of such person's previous sexual experience with any person shall not be relevant on the issue of such consent or the quality of consent."

\section{Section - 26}

For section 114A of the Evidence Act, the following section shall be substituted, namely: '114A. In a prosecution for rape under clause 1 , clause 2 , clause 3 , clause 4 , clause 5 , clause 6 , clause 7 , clause 8 , clause 9 , clause 10 , clause 11 , clause 12 , clause 13 or clause 14 of sub-section (2) of section 376 of the Indian Penal Code, where sexual intercourse by the accused is proved and the question is whether it was without the consent of the woman alleged to have been raped and such woman states in her evidence before the court that she did not consent, the court shall presume that she did not consent. Explanation- In this section, "sexual intercourse" shall mean any of the acts mentioned in clauses $(a)$ to $(d)$ of section 375 of the Indian Penal Code.'

\section{Section 27}

For section 119 of the Evidence Act, the following section shall 
be substituted, namely:-_"119. A witness who is unable to speak may give his evidence in any other manner in which he can make it intelligible, as by writing or by signs; but such writing must be written and the signs made in open Court, evidence so given shall be deemed to be oral evidence: Provided that if the witness is unable to communicate verbally, the Court shall take the assistance of an interpreter or a special educator in recording the statement and such statement shall be video graphed."

\section{Section 28}

In section 146 of the Evidence Act, for the proviso, the following proviso shall be substituted, namely:

"Provided that in a prosecution for an offence under of section 376 , section376A, section $376 \mathrm{~B}$, section $376 \mathrm{C}$, section $376 \mathrm{D}$ or section $376 \mathrm{E}$ of the Indian Penal Code or for attempt to commit any such offence, where the question of consent is an issue, it shall not be permissible to adduce evidence or to put questions in the cross examination of the victim as to the general immoral character, or previous sexual experience, of such victim with any person for proving such consent or the quality of consent."

\section{Suggestion and conclusion}

i. It is duty of the doctor or hospital who examines the rape victim to care and protect the rape victim and for that purpose to give medical examination and care without police requisition. So far, the rape survivor examination can only be done after receiving police requisition. The doctor should examine such cases if the survivor reports to the hospital first without the FIR.

ii. The victim must not be refused treatment and examination for want of police papers.

iii. In case the survivor doesn't want to disclose the incident to the police, it should not be done. However, the refusal for not informing the police should be documented.

iv. The medical examination should be undertaken only if the victim, parents or guardians wish for it. Neither court nor police can force the survivor to undergo medical treatment.

v. Consent of the patient should be taken for medical examination and treatment, forensic medical examination and collection of evidence, informing the police for purpose of investigation and treatment.

vi. In case a female patient is to be examined by a male doctor then such examination shall be made in presence of a female nurse/ attendant/ etc. In such circumstances the name and signature of the female in whose presence the examination is conducted shall also be obtained.

\section{Acknowledgments}

None

\section{Conflicts of interest}

The author declares that there is no conflict of interest. 